\title{
8 \\ Use of SLAMM in Evaluating Best Management Practices
}

\author{
Robert Myllyoja, Hala Baroudi, Robert Pitt and Jeanna Paluzzi
}

Once baseline water quality data reveals that beneficial uses of a stream are no longer supported, the task of evaluating alternatives for urban watershed management can be challenging for municipal planners. While working with the municipalities within the Bear Creek watershed to develop a watershed management plan, the Clinton River Watershed Council selected the Source Loading and Management Model (SLAMM) as the main instrument. A costeffective management tool was required to assist in evaluating the effectiveness of urban best management practices (BMPs). Evaluating the suitability of the model was difficult because we were not aware of any previous SLAMM applications in the State of Michigan. The objective became, not only to learn about and apply the model, but also to demonstrate its applicability in similar Michigan watersheds.

The Source Loading and Management Model (Pitt, 1998; Pitt and Voorhees 1995) emphasizes the use of variable quality of runoff, small storm hydrology, and particulate washoff to calculate runoff pollutant yield estimates. Unlike drainage design models, SLAMM accurately computes runoff pollutant loads and flows associated with small storm events. This is critical because most of the pollutant load is associated with the smaller, frequent runoff events.

SLAMM evaluates several control practices including detention ponds, infiltration devices, porous pavements, grass swales, catchbasin cleaning, and street cleaning. These controls can be evaluated in combinations at many source areas and at the outfalls. Furthermore, SLAMM computes the relative

Myllyoja, R., H. Baroudi, R.E. Pitt and J. Paluzzi. 2001. "Use of SLAMM in Evaluating Best Management Practices." Journal of Water Management Modeling R207-08. doi:

10.14796/JWMM.R207-08.

(c) CHI 2001 www.chijournal.org ISSN: 2292-6062 (Formerly in Models and applications to Urban Water Systems. ISBN: 0-9683681-4-X) 
contributions of different source areas (e.g. roofs, streets, parking areas, landscaped areas, undeveloped areas) for each land use investigated. SLAMM requires the user to define specified impervious areas and directly connected impervious areas (DCIAs) within the model's subwatershed. DCIAs include those impervious areas that flow directly to a storm sewer, drain, channel, or waterway without flowing over any pervious surfaces. SLAMM utilizes sitespecific local information including stormwater conveyance system type and condition, study period duration, rainfall depth, duration, and, and detailed land use and source area descriptions. SLAMM does not require detailed drainage system information, although the newest version of the program allows interfacing with SWMM for detailed hydraulic system evaluations.

\subsection{Background}

Bear Creek is a seven-mile $(11 \mathrm{~km})$ long, urbanized headwater tributary of the Red Run Drain in the Clinton River watershed that flows into Lake St. Clair. All of its tributaries are piped and only three miles $(5 \mathrm{~km})$ of the creek are open channel. It drains an 18.8 square mile $\left(48.6 \mathrm{~km}^{2}\right)$ area mostly within the City of Warren. Bear Creek is protected by the State of Michigan for warm water fish and other indigenous wildlife, partial and total body contact recreation from May to October, navigation, industrial water supply, public water supply at the point of water intake, and agricultural uses. Water quality data suggests that beneficial uses are threatened or not supported due to elevated levels of fecal indicator bacteria, metals, and salts. A 1997 creek corridor survey documented oil sheens, high turbidity, significant streambank erosion, and excessive algae growth. These problems contribute to the Clinton River watershed's designation as an Area of Concern under a U.S.-Canadian program to implement the Great Lakes Water Quality Agreement. The problems were recommended for remediation in the 1995 Clinton River Remedial and Preventative Action Plan Update. It is also suspected that the continuous contribution of fecal indicator bacteria to the Red Run Drain may be partly responsible for beach closings on the western shore of Lake St. Clair, near the mouth of the Clinton River and the Clinton River Spillway, since 1994.

A steering committee comprising concerned residents, city, county and state officials, and representatives of local industry was responsible for the development and ultimate implementation of the watershed management plan. Initial treatment BMPs to address the nonpoint source pollutants impacting Bear Creek were identified by developing a BMP screening procedure. The screening procedure was based on physical suitability, pollutant removal benefits, maintenance requirements, environmental amenities, and costs. 
Stormwater retention benefits were not determined during the screening procedure because the design storm for flood control generally bypasses water quality BMPs. SLAMM results were the primary tool in recommending BMPs to apply to the entire watershed. In addition, this information was used to refine our original pollutant load estimates based on Schueler's Simple Method and other methods (Center for Watershed Protection, 1996).

\subsection{Methodology}

Environmental indicators are chosen parameters and indices which can be used to characterize overall conditions in receiving water and can be used to provide benchmarks for assessing the success of watershed management efforts (Claytor and Brown, 1996). The steering committee identified current surface water quality standards as pollutant removal targets for watershed BMPs. Historical and recent water quality sampling data including inorganic chemical, organic chemical, biological, and physical parameters for Bear Creek and its tributaries, were compiled. All data exceeding criteria based on either Michigan Department of Environmental Quality, Michigan Department of Public Health or, where state guidelines were not available, EPA surface water quality guidelines were identified. Those parameters that exceeded the water quality criteria were indicated as pollutants of concern.

The Bear Creek watershed was subdivided into twelve subwatersheds based on available storm sewer mapping. To improve accuracy, simplify procedures, and stay within the timeline and available budget, a representative subwatershed was selected. Ideally, extremely accurate measurements of all source areas would be calculated for the entire watershed. However, the level of accuracy had to be balanced with other watershed planning needs.

The Centerline Relief subwatershed was selected as being representative of the entire watershed for application of the SLAMM model. The Centerline Relief subwatershed was identified due to elevated parameters typically found in other subwatersheds including copper, total phosphorous, biological oxygen demand, total suspended solids, and fecal indicator bacteria. Furthermore, its land uses were similar to those of other subwatersheds with 50\% developed for residential and $50 \%$ for commercial/industrial uses.

The following activities were undertaken to address the BMP screens:

- physical suitability analysis

- BMP pollutant removal efficiency analysis

- maintenance level analysis

- economic suitability analysis

- environmental amenity analysis 
- summary of current nonstructural BMPs

- request to steering committee for input

To analyze physical suitability of a BMP for a specific land use application, candidates were screened, based on space availability, soil types, appropriate slopes, water table proximity, and critical areas. A literature search of research results was also helpful in determining the applicability of each BMP to an urban watershed and its specific land uses (Claytor and Schueler, 1996). Limitations in available space were a critical part of the screening procedure due to the ultraurban nature of the Bear Creek area. It was recommended that the space requirements of some BMPs be incorporated into the design for redeveloped sites and that other controls, which require no surface space, be selected for retro-fitting opportunities.

The BMPs were screened for pollutant removal efficiencies based on the results of SLAMM modeling and research of existing studies (e.g. Brown and Schueler, 1997). Required maintenance levels were evaluated based on experience and research. A cost analysis of various BMPs was also evaluated through experience and research of local studies.

Environmental features were an essential screening stage. They create a public signature with native plants contributing to urban habitat values. They also enhance watershed ecological quality and biodiversity at a reduced cost. The Clinton River Watershed Council is actively promoting watershed restoration, composting, healthy lawn and garden practices, and innovative ways of managing infrastructure with garden amenities where streets or storm systems are repaired or replaced. The absence of sensitive areas and endangered species was also confirmed.

Additional input was also requested from the participating municipalities in the form of a questionnaire that summarized their current street sweeping, catchbasin cleaning, and other nonstructural practices.

\subsubsection{Land Use Analysis}

Digital land use maps were acquired, the Centerline Relief Drain subwatershed was delineated from an existing GIS aerial photo, and the drainage area was calculated. The areas of each land use within the subwatershed were derived from $1^{\prime \prime}=100^{\prime}(1 \mathrm{~mm}=1.2 \mathrm{~m})$ aerial photographs (Table 8.1). Observations and measurements were performed in the field at residential subdivisions to precisely determine the dimensions of typical source areas within a lot such as sidewalks, streets, houses, driveways, landscaped areas, and garages. Comparison of digital, aerial, and field measurements shows acceptable levels of accuracy. Field investigations confirmed whether roof runoff was directly connected to the storm sewer. 
Table 8.1 Summary of land use areas (acres) for Centerline Relief.

\begin{tabular}{lcccccccc}
\multicolumn{1}{c}{$\begin{array}{c}\text { Land Use } \\
\text { Description }\end{array}$} & $\begin{array}{c}\text { Percent } \\
\text { DCIA }\end{array}$ & Street & $\begin{array}{c}\text { Paved } \\
\text { Parking }\end{array}$ & Grass & Walk & Buildings & $\begin{array}{c}\text { Unpaved } \\
\text { Parking }\end{array}$ & $\begin{array}{c}\text { Land Use } \\
\text { Area }\end{array}$ \\
\hline Forest/ Rural Open & N/A & & & & & & & 15.0 \\
Urban Open & N/A & 0.3 & & 29.6 & 0.4 & & 1.8 & 32.0 \\
$\begin{array}{l}\text { Agricultural/ Pasture } \\
\text { Low Density }\end{array}$ & N/A & & & & & & & \\
$\begin{array}{l}\text { Residential } \\
\text { Medium Density }\end{array}$ & N/A & & & & & & & \\
$\begin{array}{l}\text { Residential } \\
\text { High Density }\end{array}$ & 0 & 62.9 & 63.2 & 239.5 & 15.6 & 138.4 & & 519.7 \\
$\begin{array}{l}\text { Residential } \\
\text { Commercial }\end{array}$ & 0 & 2.4 & 11.7 & 19.5 & 1.0 & 8.6 & & 43.3 \\
$\begin{array}{l}\text { Industrial } \\
\text { Highway }\end{array}$ & 100 & 70.4 & 173.8 & 59.0 & 8.6 & 95.8 & 5.0 & 412.6 \\
\hline
\end{tabular}

\subsection{SLAMM Implementation}

The SLAMM model evaluated the watershed pollutant levels of TSS, total phosphorus, BOD, and total copper during a three month period corresponding to the protected swimming season along Lake St. Clair. Detroit Metro Airport rainfall data was used as a driving mechanism for the projection of stormwater pollutant loadings. Recent water quality data from grab samples at major tributary outfalls was available for the entire watershed. SLAMM's existing pollutant loading file was used, however, because source area water quality data was not available. The following list outlines a general description of the SLAMM baseline model:

- $100 \%$ of area drains to curb and gutter drainage (in fair condition).

- $100 \%$ of residential roofs drain to pervious areas.

- $0 \%$ of commercial and industrial roofs drain to pervious areas.

- $100 \%$ of driveways drain to impervious gutters.

- $100 \%$ of streets of intermediate texture (roughness).

- No street cleaning.

- No catchbasin cleaning.

A total catchbasin sump volume of $950 \mathrm{ft}^{3}$ per 100 acres $\left(66 \mathrm{~m}^{3}\right.$ per 100 ha) for the Centerline Relief subwatershed was investigated using SLAMM with the sumps $50 \%$ full at the beginning of the study period and cleaned out in the middle of the study period. A 167 acre ( $68 \mathrm{ha}$ ) redevelopment area was modeled 
with $2 \mathrm{ft}$ wide swales added along all existing roads and with a detention basin designed for $80 \%$ TSS removal. A swale width of $2 \mathrm{ft}(0.6 \mathrm{~m})$ was assumed due to space constraints. A 255 acre (104 ha) redevelopment area was also modeled with a detention basin designed for $80 \%$ TSS removal. Street cleaning frequencies of every 12 weeks and every 8 weeks were investigated for all streets within the subwatershed.

\subsection{Results and Analysis}

The BMPs were screened for pollutant removal efficiencies based on research of existing studies and SLAMM modeling. Due to differences in design, components, installation, and pollutant input loadings, the results of modeling (Figure 8.1) and literature search showed high variability in pollutant removal efficiencies of some source area controls.

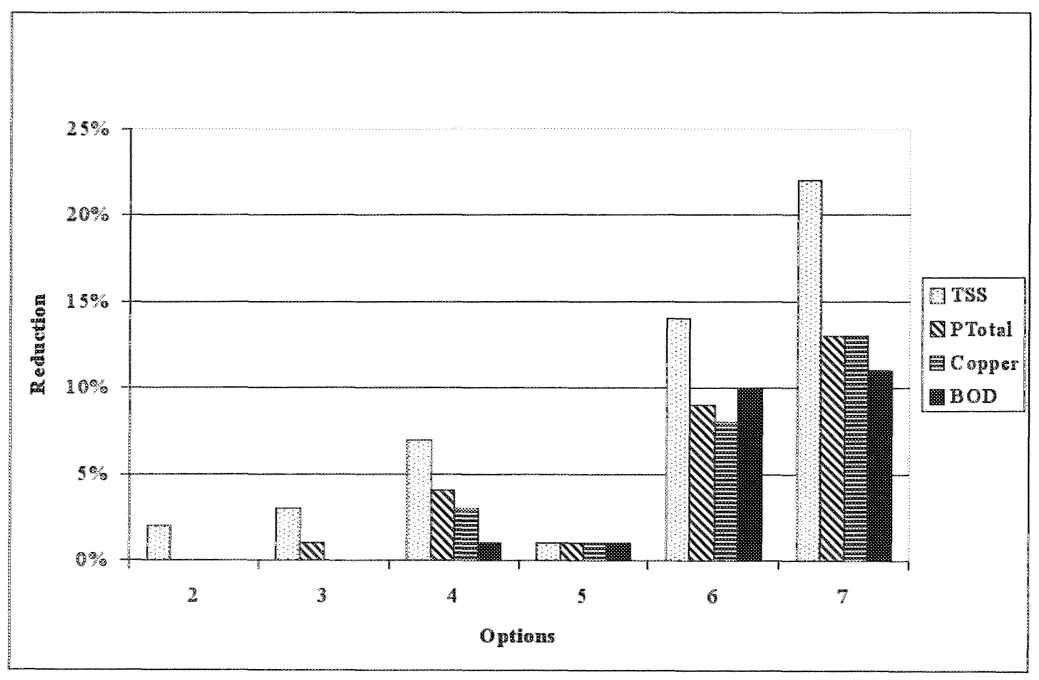

Figure 8.1 SLAMM estimated pollutant reductions.

\subsubsection{Open Vegetated Channels}

Open channels or grass swales are often used to convey stormwater runoff. In some cases, traditional open channels can be redesigned to offer significant pollutant removal. To meet water quality criteria, grass channels must provide broader bottoms, lower slopes, denser vegetation, and greater residence time 
than drainage channels. Nominal pre-treatment is also achieved through placing checkdams at various points along the channel. Dry swales temporarily detain stormwater with a checkdam before passing through a filter bed to an underground perforated pipe. Wet swales act as a long shallow wetland treatment system where standing water within a series of cells is treated through settling and emergent vegetation.

The use of grass swales within a redeveloped area that was $11 \%$ of the total subwatershed was evaluated using the SLAMM model. This was the only control investigated that could provide infiltration. Due to the narrow $2 \mathrm{ft}(0.6$ $\mathrm{m})$ swale width (assumed because of space constrictions) and the clay-type soils, there was little effect on the overall runoff volume. Vegetation and other infiltration media, increased width, and reduced slopes could be designed into redeveloped right-of-ways to greatly improve swale effectiveness. Without the benefit of infiltration runoff, the swales provided low pollutant removal efficiencies (Table 8.2). Other field studies show $>80 \%$ TSS reduction for wet and dry swales (Claytor and Schueler, 1996). SLAMM evaluations of swale effectiveness may differ from recent studies due to innovations in grass channel design. Vegetated swales of various designs can provide excellent removal of nutrients, trace metals, and TSS. However, grass and other forms of vegetation may quickly lose their effectiveness when blocked with fine silts.

\subsubsection{Wet Detention Basins}

SLAMM was used to evaluate the benefits of installing a wet detention basin within the 167 acre ( $68 \mathrm{ha}$ ) redeveloped area equal to $11 \%$ of the total area of the Centerline Relief subwatershed. A wet detention basin was also evaluated within another 255 acre (104 ha) redeveloped area that is equal to $17 \%$ of the total area of the subwatershed. Results showed the basins were very effective in reducing levels of TSS, total phosphorus, total copper, and BOD (Table 8.2).

Wet detention basins have a stabilized inlet and have standing water at least three feet $(0.9 \mathrm{~m})$ deep between rains. Study results show average reductions by wet detention basins of $62.4 \%$ for TSS, $14.7 \%$ for copper, and $53.4 \%$ for phosphorus (Brown and Schueler, 1997). Observed pollutant reduction values are highly variable depending on design, pollutant input, and maintenance.

Wet detention basins are effective in reducing TSS and particulate forms of pollutants, yet are less effective in removing soluble metals and bacteria. Basins can require a higher initial cost, although they seem to last longer and provide water quality and quantity control with acceptable maintenance and good value. They require considerable space, however, and may not be an option in urbanized areas. 


\subsubsection{Nonstructural BMPs}

The use of a mechanical street sweeper was evaluated with the SLAMM model. Mechanical street sweeping was not very effective at reducing TSS and total phosphorus and had no effect on BOD or copper levels. Street sweeping resulted in minimal TSS or phosphorus reductions with both 12 week and 8 week frequencies (Table 8.2).

The level of catchbasin sump cleaning that was investigated for the watershed was once during the middle of the study period. Catchbasin sump cleaning showed limited TSS, total phosphorus, and total copper reduction and had no effect on BOD levels.

Other studies show a TSS reduction of 5-30\% reduction for mechanical sweeping and $40-80 \%$ for high efficiency sweeping (Claytor and Schueler, 1996), under optimal conditions. However, Michigan's variable winter conditions would influence these results.

The use of catchbasin cleaning and street cleaning together was evaluated with SLAMM and provided a 9\% reduction in TSS. The use of swales and a detention basin together in a 167 acre redeveloped area was evaluated and a 15\% TSS reduction was realized. A combination of all controls together was examined resulting in a $22 \%$ reduction in TSS (Table 8.2 ).

Table 8.2 SLAMM results: percentages of pollutant removal.

\begin{tabular}{clcccc}
\hline \multicolumn{1}{c}{ Option } & \multicolumn{1}{c}{ TSS } & P & Cotal & Copper & BOD \\
\hline 1 & None & $0 \%$ & $0 \%$ & $0 \%$ & $0 \%$ \\
2 & Street sweeping every 12 weeks & $2 \%$ & $0 \%$ & $0 \%$ & $0 \%$ \\
3 & Street sweeping every 8 weeks & $3 \%$ & $1 \%$ & $0 \%$ & $0 \%$ \\
4 & One catchbasin cleaning & $7 \%$ & $4 \%$ & $3 \%$ & $1 \%$ \\
5 & 2ft. wide swales (112.6 ft/acre) & $1 \%$ & $1 \%$ & $1 \%$ & $1 \%$ \\
& within 167 ac. redeveloped area & & & & \\
6 & Detention basin servicing & $14 \%$ & $9 \%$ & $8 \%$ & $10 \%$ \\
7 & 167 ac. redeveloped area & $22 \%$ & $13 \%$ & $13 \%$ & $11 \%$ \\
& Detention basin servicing & & & & \\
8 & 255 ac. redeveloped area & $15 \%$ & $10 \%$ & $9 \%$ & $11 \%$ \\
9 & Options 5 and 6 & $9 \%$ & $4 \%$ & $3 \%$ & $1 \%$ \\
10 & Options 2 and 4 & $22 \%$ & $10 \%$ & $17 \%$ & $4 \%$ \\
\hline
\end{tabular}

Adapted from HRC, Inc. (1999)

\subsubsection{Infiltration Devices}

Infiltration devices were not considered to be option at this time. These devices are beneficial from a groundwater recharge standpoint, yet require pretreatment and frequent maintenance when they become clogged and their percolation 
rates decline. Due to the clayey soils present and their limited use in southeast Michigan, they were not evaluated.

\subsection{Recommendations}

Following completion of physical suitability, BMP pollutant removal efficiency analysis, maintenance level, economic suitability, and environmental amenity analyses, input was requested from the Steering Committee on tentative recommendations.

Physical suitability of each BMP was evaluated. The selection of possible sand filters was reduced to underground, perimeter, and pocket sand filters. Due to size restrictions, wet detention basins were an option only in redeveloped residential subdivisions and large industrial sites. The design of grass channels makes them an ideal option along highways. Available pervious space is limited due to the urbanized nature of the watershed, therefore, nonstructural practices, sand filters, proprietary source area controls, and bioretention areas were recommended.

Based on improved pollutant removal efficiencies, sand filters and bioretention systems were recommended. Grass channels alone were not recommended. A pilot study on the feasibility of an alum treatment program and further investigation of street and catchbasin cleaning alternatives was recommended.

Table 8.3 Summary of recommended best management practices.

\begin{tabular}{ll}
\multicolumn{1}{c}{ Land Use Category } & Recommendation \\
\hline $\begin{array}{l}\text { Residential Subdivision } \\
\text { Development }\end{array}$ & $\begin{array}{l}\text { Garden Amenities } \\
\text { Bioretention Areas } \\
\text { Wet Detention Basins }\end{array}$ \\
Residential Infrastructure & Off-line Bioretention Areas \\
Commercial Sites & Proprietary Stormwater Devices \\
Industrial Areas & Proprietary Stormwater Devices \\
& Detention Basins with Biofiltration Areas Sand Filters \\
Parking Lots & Offline Bioretention System \\
& Proprietary Stormwater Devices \\
& Filter Strips \\
Streets and Highways & Grass Channels \\
& Dry Swales \\
Nonstructural BMPs & Offline Bioretention Areas \\
& Evaluate High Efficiency Street Sweeping \\
& Annual Catchbasin Cleaning \\
& Study Feasibility of Alum Treatment \\
&
\end{tabular}


Economic suitability screening was mainly based on cost of operation and maintenance practices. This eliminated the use of sand filters in most applications. Several source area control devices were recommended for smaller sites or portions of critical sites.

Based on environmental amenity screening, offline bioretention areas and bioretention systems were recommended. One proprietary source area control device also provides some aesthetic value to small commercial sites.

\subsection{Conclusions}

The implementation of the Bear Creek Watershed Management Plan is part of an ongoing effort by the Clinton River Watershed Council and the Bear Creek Steering Committee. The Watershed Council has begun sponsoring public and municipal education initiatives and the Steering Committee is evaluating ways of implementing the Watershed Management Plan in phases and integrating it into municipal and county programs.

The study's recommendations were preliminary and additional data should be examined before adopting site-specific designs.

Several considerations for future applications of SLAMM include:

- a representative rainfall year file could be developed using several decades of rain information;

- the model could be effectively applied to a smaller specific land use site such as the redevelopment of an industrial area;

- results could be confirmed and the model further calibrated with a water quality study of local source areas; and

- experience with interpreting output and with SLAMM's limitations is important when screening BMPs.

While a useful planning tool, SLAMM is limited in the types of BMPs it can evaluate. For example, only mechanical street sweeping can be evaluated. Perhaps the SIMPTM model could be considered for further evaluation of sediment trapping catchbasins, catchbasin cleaning, and high efficiency street sweeping practices (Sutherland and Jelen, 1998). SLAMM requires precise, time consuming measurement of source areas. Training programs and technical support were limited.

SLAMM is an effective stormwater quality planning tool that computes concentrations, loadings, and flow volumes for a rain series. It provides simple estimates for a large variety of potential conditions and requires a minimal amount of information to evaluate an area. SLAMM can be used with GIS and is being continually updated and expanded. The windows version using Visual Basic, winSLAMM V8.0, is currently available. 


\section{Acknowledgments}

This study was initiated by the financial support of the Michigan Department of Environmental Quality through a U.S. Environmental Protection Agency Section 319 planning grant. In particular, the authors gratefully acknowledge representatives of the Bear Creek Steering Committee and the Clinton River Watershed Council for providing ongoing support of the watershed management plan's implementation.

\section{References}

Brown, W.B. and T.R. Schueler, 1997, National Pollutant Removal Performance Database for Stormwater BMPs: a national examination of pollutant removal capability, Center for Watershed Protection, Silver Spring, MD, pp.189.

Camp, Dresser \& McKee, Larry Walker Associates, Uribe and Associates, Resources Planning Associates, 1993, California Stormwater Best Management Practice Handbooks: Industrial/Commercial.

Center for Watershed Protection, 1996, Simple and Complex Stormwater Pollutant Load Models Compared. Watershed Protection Techniques, Vol. 2, No. 2, Spring, pp.356-368.

Claytor, R.A. and W. E. Brown, 1996, Environmental Indicators to Assess Stormwater Control Programs and Practices, Center for Watershed Protection, Silver Spring, MD, pp.172.

Claytor, R.A. and T. R. Schueler, 1996, Design of Stormwater Filtering Systems, Center for Watershed Protection, Silver Spring, MD, pp.177.

Hubbell, Roth \& Clark, Inc., 1999, Restoring Bear Creek and Decreasing Fecal Bacteria and Other Nonpoint Source Loadings into the Red Run Drain: Final Technical Report, Hubbell, Roth \& Clark, Inc.

Michigan Department of Environmental Quality, 1995, Clinton River Watershed Remedial and Preventative Action Plan: 1995 Update, Lansing, MI.

Pitt, R.E. 1998. "Unique Features of the Source Loading and Management Model (SLAMM)." Journal of Water Management Modeling R200-02. doi: 10.14796/JWMM.R200-02.

Pitt, R. and J. Voorhees, April 1995, Source Loading and Management Model (SLAMM) from National Conference on Urban Runoff Management: Enhancing Urban Watershed Management at the Local, County, and State Levels, EPA/625/ R-95/003, Center for Environmental Research Information, U.S. E.P.A., Cincinnati, Ohio, pp.225-243.

Schueler, T.R., 1987, Controlling Urban Runoff: a practical manual for planning and designing urban BMPs., Publ. No. 87703, Metropolitan Washington Council of Governments, Washington D.C.

Sutherland, R. C. and S. Jelen, 1998, Simplified Particulate Transport Model - User's Manual Version 3.2, pp.34. 
